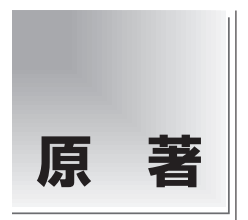

論文受付 2020 年 3 月 13 日

論文受理 2021 年 5 月 6 日 Code No. 621

\section{一般撮影領域における面積線量計を用いた 被ばく線量管理についての検討}

\author{
中野伸哉 ${ }^{1}$ 中川英雄 ${ }^{2}$ 津上唯佳 ${ }^{2}$ 藤田知子 $^{2}$ 中村悦子 $^{2}$ 琴浦規子 $^{2}$ \\ ${ }^{1}$ 兵庫医科大学病院放射線技術部(現 富士フイルムメディカル株式会社) \\ 2 兵庫医科大学病院放射線技術部
}

\section{緒 言}

2020 年度より computed tomography (CT) 検査など のモダリティにおいて被ばく線量の記録管理が義務化 される。一般撮影領域については今回該当しないが, 今後, 線量の記録が義務化されると考えられる。国際 放射線防護委員会 (International Commission on Radiological Protection: ICRP)は, 防護の最適化の指 標として診断参考レベル (diagnostic reference levels: DRLs)の適用を勧告しており ${ }^{1)}$ ，一般撮影領域では入 射表面線量 (entrance surface dose: ESD)の值が用いら れている。 ESDの算出方法としては, 熱蛍光線量計を 用いて直接計測する方法や撮影条件から計算によって
算出する表面線量簡易換算法 (numerical dose determination: NDD 法) などが挙げられるが2 ${ }^{2 \sim 4)}$, Japan DRLs 2015 では, 電離箱線量計による計測を標準と し, 電離箱線量計の測定值を用いて標準体型を想定し た被写体厚におけるESDにて評価するとされてい る ${ }^{5)}$. しかし, この方法は, 焦点-被写体間距離や撮影 ごとの撮影条件を基に計算を行う必要があり，個人の 被ばく線量の記録に用いることは困難と考えられる. 当院では，2019 年 8 月に面積線量計を搭載した X 線 発生装置が導入され，撮影ごとの面積線量を把握する ことが可能となった。面積線量計は, interventional radiology (IVR)領域では広く用いられており, 面積線

\title{
A Study of Patient's Dose Control at Radiography by Using a Dose Area Product Meter
}

\author{
Shinya Nakano, ${ }^{1 *}$ Hideo Nakagawa, ${ }^{2}$ Yuika Tsugami, ${ }^{2}$ Tomoko Fujita, $^{2}$ Etsuko Nakamura, ${ }^{2}$ \\ and Noriko Kotoura ${ }^{2}$ \\ ${ }^{1}$ Department of Clinical Radiology, The Hospital of Hyogo College of Medicine Hospital (Current address: FUJIFILM \\ Medical Co., Ltd) \\ ${ }^{2}$ Department of Clinical Radiology, The Hospital of Hyogo College of Medicine Hospital
}

Received March 13, 2020; Revision accepted May 6, 2021

Code No. 621

\section{Summary}

Purpose: The International Commission on Radiological Protection recommends adaptation of the diagnostic reference levels (DRLs). Japan DRLs 2020 apply the entrance surface dose (ESD) in radiography. However, it is difficult to measure ESD in the clinical setting. A dose area product meter has been proposed for use as a dose index in interventional radiology. We investigated the basic characteristic of a dose area product meter and the relationship of ESD and dose area product meter values in radiography. Method: We measured calibration factors from phantom studies and estimated ESD from the dose area product meter. Subject thickness was measured from the chest clinical images for calculation of ESD. Estimated ESD from the dose area product meter was compared with that calculated from program software (Surface Dose Evaluation Code, Sdec). Result: Relative dose (dose area product meter/ionization chamber) decreased when tube voltage was lower $(60 \mathrm{kV})$ or higher $(130 \mathrm{kV})$. A positive correlation was found between the estimated and calculated ESD. Conclusion: Dose area product meter can be used for patient's dose control in radiography.

Key words: radiography, dose area product meter, entrance surface dose

*Corresponding author 

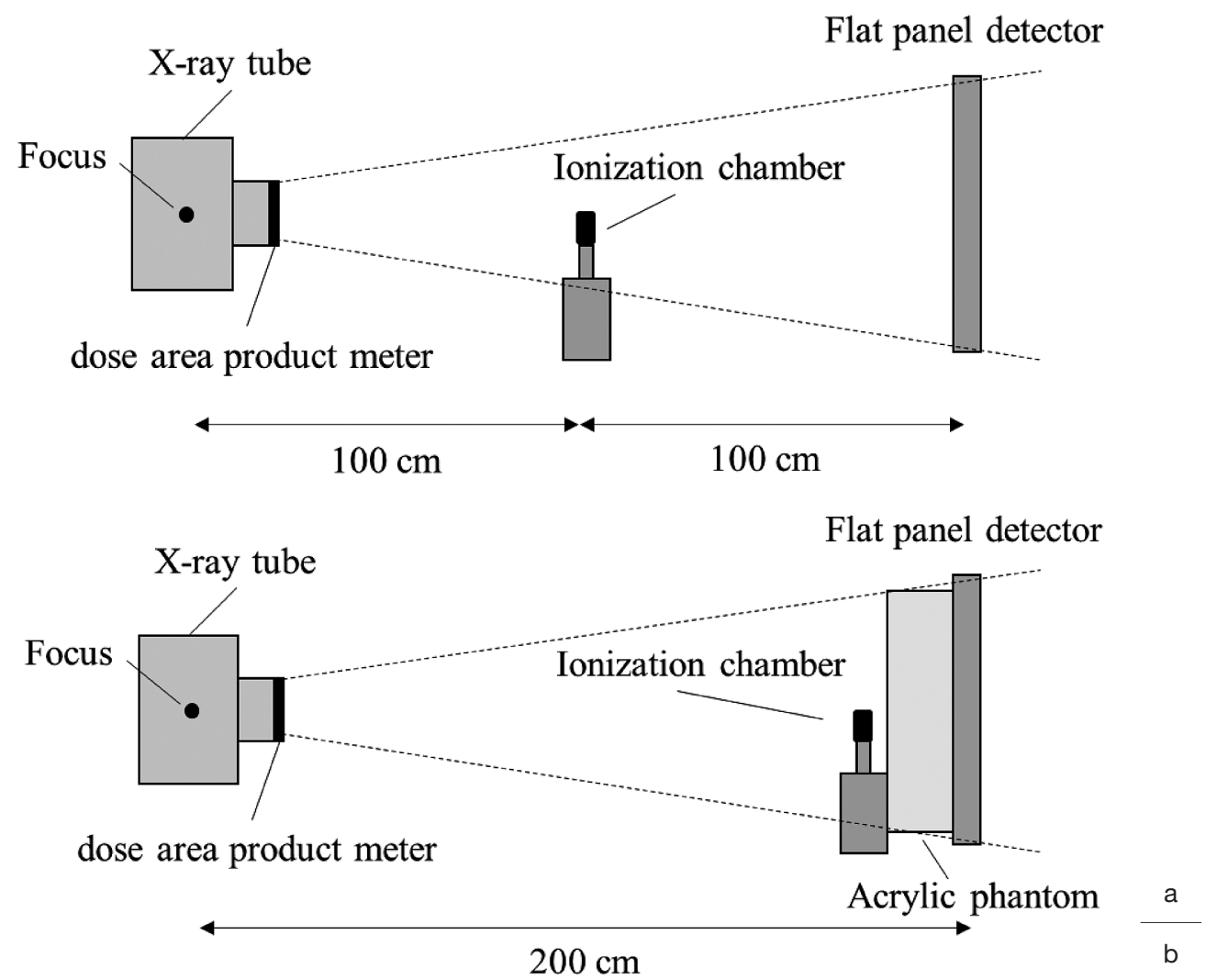

Fig. 1 (a) Geometry for dosimetry

(b) Geometry for backscatter factor calculation

量計の基本特性および校正定数を把握することで簡便 に入射皮膚線量を推定可能であると報告されてい

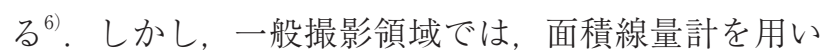
た被ばく管理に関する報告は少なく, ESD の推定につ いての報告はない，今回，一般撮影領域に拈ける面積 線量計の基本特性の把握および胸部正面撮影時の ESDの推定を試みたので報告する.

\section{1. 方 法}

\section{1-1 使用機器}

一般撮影装置は島津製作所 (京都) 製 RADspeed Pro を, FPD 装置は富士フイルム (東京)製 CALNEO Smart C77を用いた。線量測定には, VacuTec(Dresden, Germany）製の面積線量計 VacuDap-OEM， Radcal (Monrovia, CA, USA) 製の指頭型電離箱線量計 Radcal 9015 型 (6 cc) および線量計算ソフトウェア Sdec-V15 (藤田医科大学，愛知）を用いた。

\section{1-2 面積線量計の基本特性}

\section{1-2-1＼cjkstart線質特性および線量特性}

Figure 1a に測定時の配置を示すＸ線管焦点から $100 \mathrm{~cm}$ の位置に電離箱線量計を設置し, 管電流 250

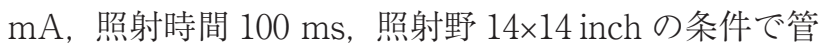
電圧を 50-140 kV に変化させた場合(線質特性) と管 電圧 $120 \mathrm{kV}$, 管電流 $250 \mathrm{~mA}$, 照射野 $14 \times 14$ inch の条 件下で照射時間を 10-500 ms まで変化させた場合(線 量特性)で電離箱線量計の測定値とX 線装置のコリ メー夕に装備された面積線量計の表示值を比較した。 ただし, 電離箱線量計, 面積線量計ともに温度, 気圧 補正を行った值を用い，面積線量計の表示值は FPD 表面に扮ける照射面積で補正を行った值 $[\mu \mathrm{Gy}]$ とする.

\section{1-2-2 個体差}

$\mathrm{X}$ 線発生装置に装備された面積線量計 4 台を対象 とし，管電圧 $120 \mathrm{kV}$ ，管電流 $250 \mathrm{~mA}$, 照射時間 100 ms, 照射野 14×14 inch の条件で 1-2-1 と同様の位置に 配置した電離箱線量計の測定值と面積線量計の表示值 を記録し，面積線量計間での個体差を比較した。

\section{1-2-3 後方散乱の影響}

後方散乱の補正係数を求めるため, FPD 前面にア クリルを配置し(Fig. 1b), 管電圧 $120 \mathrm{kV}$, 管電流 250 $\mathrm{mA}, \mathrm{AEC}(+)$ 照射野 $14 \times 14$ inch, Cu $0.3 \mathrm{~mm}$ の条件で アクリル厚を 12-20 cm まで変化させて, アクリル表 面に扮ける電離箱線量計の測定值をアクリルがない状 態での測定值と相対的比較を行った，次に，同一の撮 
影条件で照射野を変化させ, アクリルあり $(10 \mathrm{~cm}) /$ な しでの電離箱線量計の測定値について比較を行った。

\section{1-3 入射表面線量}

\section{1-3-1 被写体厚の推定}

当院にて正面・側面の胸部撮影を行った 200 例を無 作為に抽出し, 正面撮影時の面積線量計の表示值と胸 部の正面および側面 X 線単純画像から計測した被写 体厚の関倸性について検討を行った。被写体厚につい ては, ImageJ (National Institutes of Health)を用いて 計測を行い, 次式 (1)より算出した ${ }^{7)}$. 当院では管電圧 $120 \mathrm{kV}$, 管電流 $250 \mathrm{~mA}, \operatorname{AEC}(+)$, 焦点-検出器間距 離(source-image receptor distance: SID) $200 \mathrm{~cm}$ で 0.3 $\mathrm{mm}$ の $\mathrm{Cu}$ フィルタを挿入して(半価層: $8.2 \mathrm{mmAl}$ ) 撮 影を行っている.

$$
\text { Estimated thickness }=A \times \frac{(S I D-B)}{S I D}
$$

A：傾面像における胸骨中央部の高さの厚み

$\mathrm{B}$ ：正面像における横隔膜レベルの体幅の半值

なお，「一般撮影領域における面積線量計を用いた 被ばく線量管理についての検討」として当施設の医学 研究倫理審査の承認(第 3351 号) を得ている.

\section{1-3-2 入射表面線量の推定}

1-3-1において被写体厚を推定した 200 例に対し, 撮影条件および推定した被写体厚から計算ソフト Sdec を用いて ESD を算出した ${ }^{8)}$ 。この ESD と面積線 量計の表示值に線質特性㧍よび後方散乱, 照射面積の 補正を行い, 次の推定式(2)で算出した值 $\left(\mathrm{ESD}_{\mathrm{DAP}}\right)$ に ついて比較した。

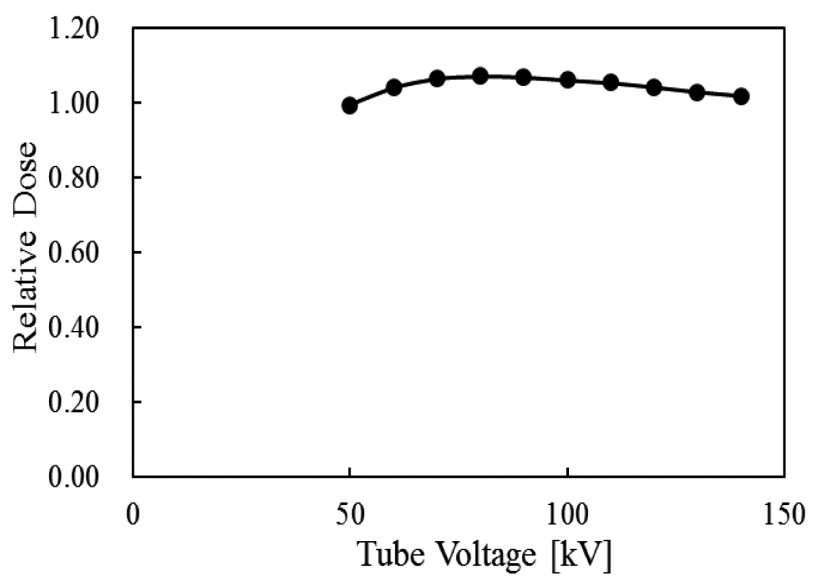

Fig. 2 Energy dependence of area product meter on tube voltage. Relative dose (dose area product meter/ionization chamber) decreased when tube voltage was lower $(60 \mathrm{kV})$ or higher $(130 \mathrm{kV})$.
$\mathrm{ESD}_{\mathrm{DAP}}=\mathrm{a} \cdot \mathrm{b} \cdot \mathrm{K}_{\mathrm{DAP}}$

$\mathrm{a}:$ 線質特性および後方散乱の補正係数

$\mathrm{b}$ ：被写体厚による照射面積の補正係数

$\mathrm{K}_{\mathrm{DAP}}$ ：面積線量計の表示値を FPD 表面での照射面 積で補正した值

\section{2. 結 果}

\section{2-1 面積線量計の基本特性}

\section{2-1-1＼cjkstart線質特性および線量特性}

管電圧の変化による相対值(面積線量計の表示值/電 離箱線量計の測定值)の変化を Fig. 2 に示す，線質特 性は，管電圧が 60-120 kV の範囲では，変動が 3\%程 度で良好だったが， $60 \mathrm{kV}$ 未満または $130 \mathrm{kV}$ 以上の 範囲では, 変動が大きくなり, 最大で $9 \%$ となった。 線量特性は直線性がよく保たれており，誤差は $2 \%$ 程 度となった(Fig. 3)。

\section{2-1-2 個体差}

今回用いたすべての面積線量計で電離箱線量計の測 定值よりも高い值を示したが，面積線量計ごとに相対 值(面積線量計の表示值/電離箱線量計の測定値)にば らつきがみられ, 個体差は, 最大で 11 ポイントとなっ た(Fig. 4).

\section{2-1-3 後方散乱の影響}

アクリル厚および照射野サイズを変化させた場合の 電離箱線量計の相対值 (アクリルあり/アクリルなし) を Fig. 5 に示す．アクリル厚㧍よび照射野サイズが 大きくなるにつれて相対值は増加したが，アクリル厚 18 $\mathrm{cm}$ 以上，照射野サイズ $35 \mathrm{~cm}$ 以上では一定となった

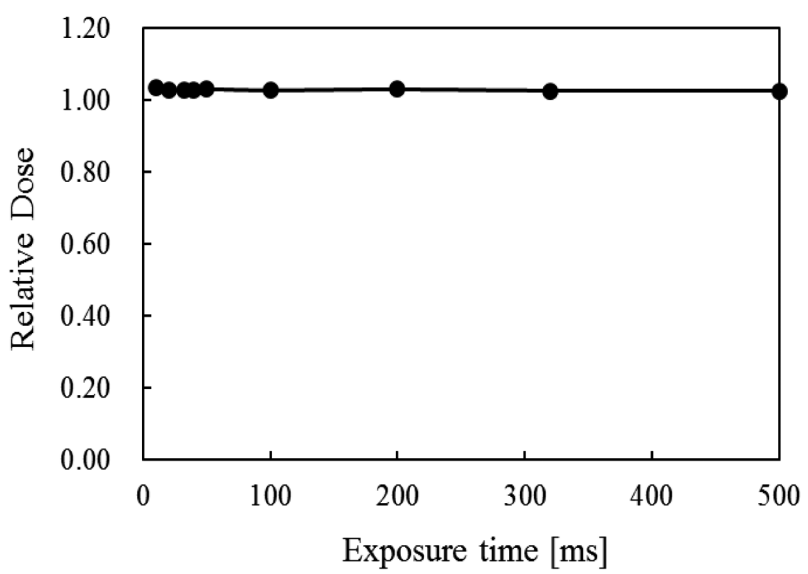

Fig. 3 Exposure dose dependence of area product meter. Relative dose (dose area product meter/ionization chamber) maintained linearity. 


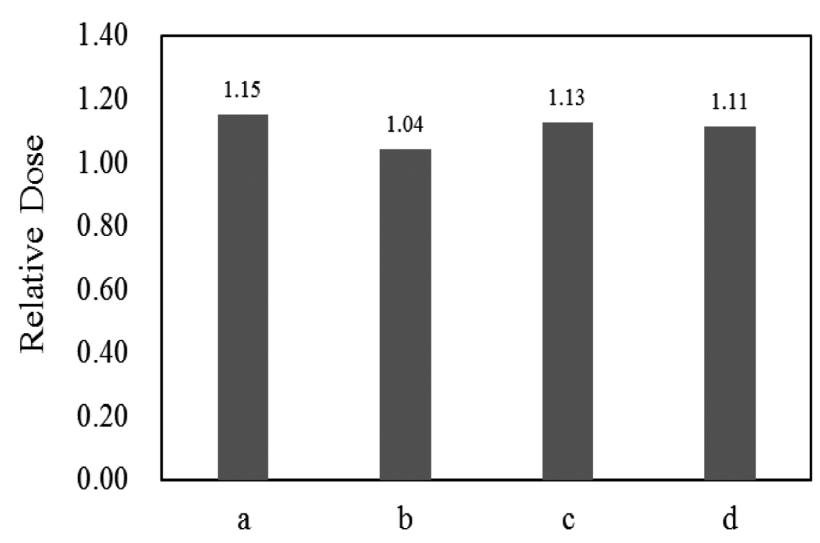

Fig. 4 An individual difference of the dose area product meters. The individual difference of four dose area product meters is lower (11 points).

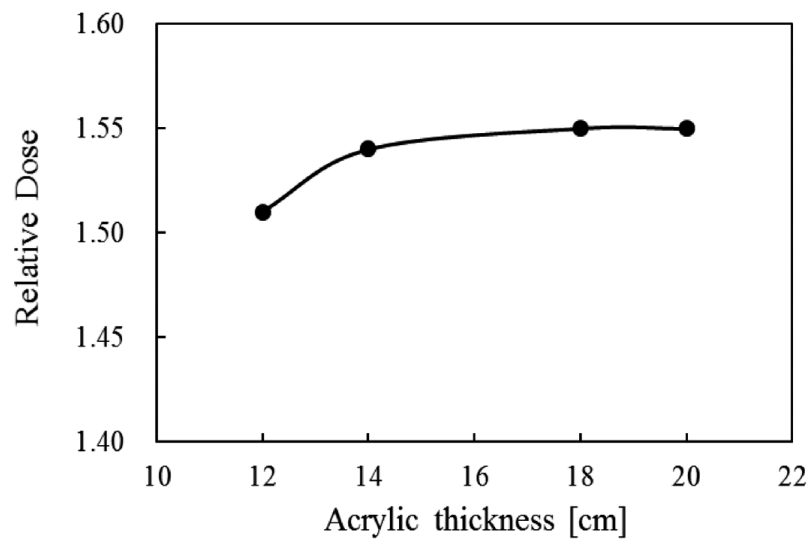

Fig. 5 Effects of backscatter.

Relative dose (acryl/air) increases as acrylic thickness and side length of square field are higher.

(a)Acrylic thickness, (b)FOV

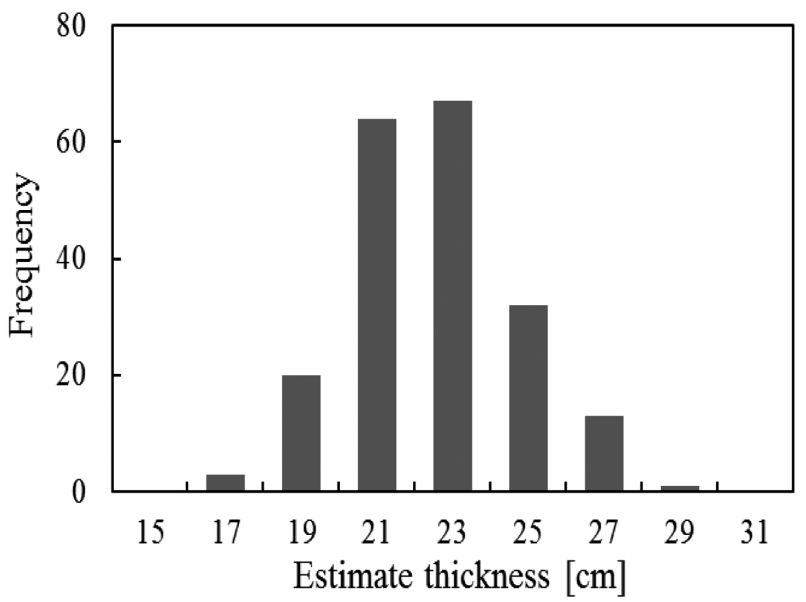

Fig. 6 Histogram of estimated thickness.

\section{2-2 入射表面線量}

\section{2-2-1 被写体厚推定}

無作為に抽出した 200 例から計測した被写体厚のヒ ストグラムを Fig. 6 に示す。被写体厚は，最小で 16 $\mathrm{cm}$, 最大で $28.8 \mathrm{~cm}$ となり, 中央值は $21.4 \mathrm{~cm}$ となっ た. Figure 7 は, 面積線量計の表示值を FPD 表面で の照射面積で補正した值 $\left(\mathrm{K}_{\mathrm{DAP}}\right)$ と被写体厚の関係性を 示す。面積線量計の表示值と被写体厚の相関係数は 0.71 となった。

\section{2-2-2 入射表面線量の推定}

$\mathrm{ESD}$ と $\mathrm{ESD}_{\mathrm{DAP}}$ を比較した結果を Fig. 8 に示す。

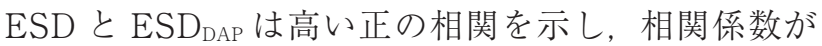
0.99，近似式は，y=1.06x-3.34 となった。なお, $\mathrm{ESD}_{\mathrm{DAP}}$ については，1-2の結果より，線質および後方散乱の

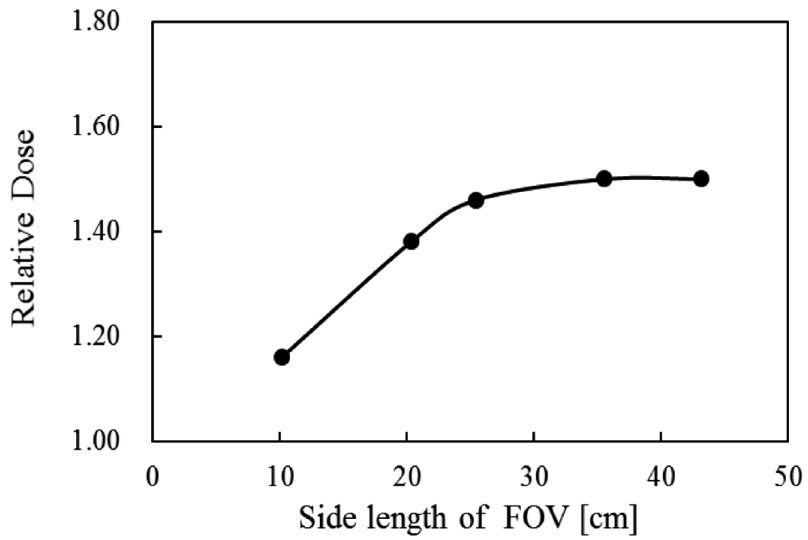

a $\mid \mathrm{b}$

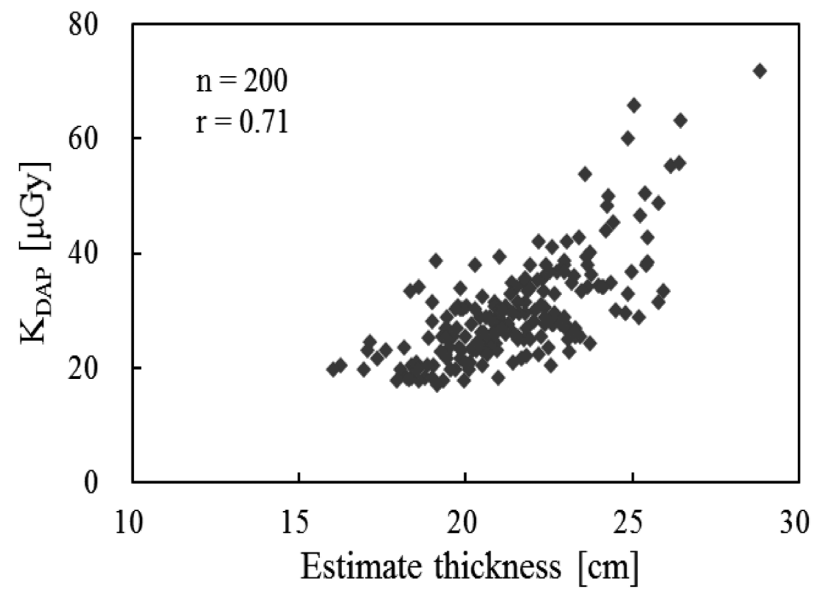

Fig. 7 Relationship between estimated thickness and dose area product meter.

The dose area product meter values $\left(\mathrm{K}_{\mathrm{DAP}}\right)$ shows a positive correlation with estimated thickness. 


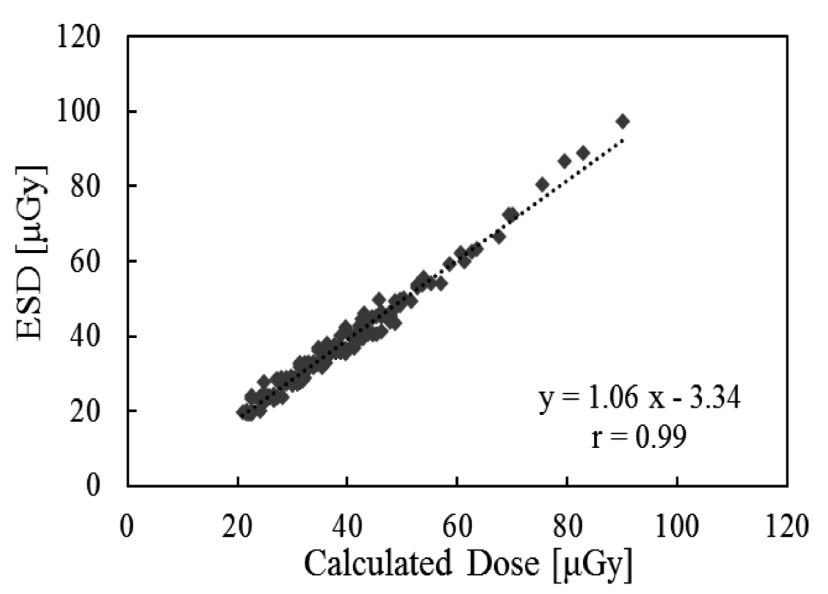

Fig. 8 Relationship between ESD and $\mathrm{ESD}_{\mathrm{DAP}}$.

There is a positive correlation between ESD and ESD $D_{\text {DAP. }}$. ESD: ESD calculated by Sdec

ESD $_{\text {DAP }}$ : ESD estimated by the dose area product meter

補正係数は照射時間 $9 \mathrm{~ms}$ 未満で 1.51 , 照射時間 $9 \mathrm{~ms}$ 以上では 1.55 とし, 被写体厚による照射面積の補正は 2-2-1の結果より，すべての症例について焦点皮膚面 距離を $180 \mathrm{~cm}$ として補正を行った。な扮 $\mathrm{K}_{\mathrm{DAP}}$ は, 面 積線量計の表示值を FPD 表面での照射面積で補正し た值とする.

(照射時間 $9 \mathrm{~ms}$ 未満) $\mathrm{ESD}_{\mathrm{DAP}}=1.51 \cdot(180 / 200)^{2} \cdot \mathrm{K}_{\mathrm{DAP}}$ (照射時間 $9 \mathrm{~ms}$ 以上) $\mathrm{ESD}_{\mathrm{DAP}}=1.55 \cdot(180 / 200)^{2} \cdot \mathrm{K}_{\mathrm{DAP}}$

\section{3. 考 察}

今回, 面積線量計の特性の把握㧍よび面積線量計の 表示値から ESD を推定する方法について検討を行っ た。面積線量計の線質特性については, 60-120 kV の 範囲では安定しているが, $60 \mathrm{kV}$ 未満または $130 \mathrm{kV}$ 以上の範囲では相対值が低くなる傾向がみられた。こ れは, 面積線量計と電離箱線量計の線質依存性の違い が影響していると考えられ, 越田らの報告と一致す $ろ^{9)}$.

線量特性については, 面積線量, 電離箱線量計の測 定値ともに線量の増加に伴い直線的に増加し, 誤差は $2 \%$ 程度であった。このことから，管電圧一定であれ ば面積線量計の表示值に線質特性の補正を行うことで 照射線量の算出が可能といえる.

個体差については, 線量計ごとにばらつきがみら れ, 最大で 11 ポイントの差がみられた。面積線量計

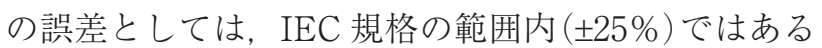
が10)，被ばく管理に用いるには大きな值であり，定期 的に精度管理を行い, 線量計ごとの校正定数を把握し て扮く必要がある。
後方散乱の影響は, 照射面積や線質によって変化す る ${ }^{11)}$. そのため, 患者ごとの後方散乱係数を把握する ためには撮影条件および照射野から計算して求める方 法があるが，すべての患者に対して行うことは困難で ある。そこで今回，アクリルを散乱体とし，散乱体の あり/なしによる電離箱線量計の測定值の比から後方 散乱の補正倸数を簡易的に算出した，照射野サイズに 関しては $35 \mathrm{~cm}$ 以上であれば一定であったことから， 胸部撮影で用いる照射野の範囲では照射野の影響は小 さいと考えられる。アクリル厚については，アクリル 厚が $18 \mathrm{~cm}$ 未満では補正係数が低值を示した。これ は，後方散乱係数が被写体厚の影響を受けるためだと 考えられる．前川は水ファントムを用いた実験におい て，ファントムの厚みが増すほど後方散乱係数は大き くなり，20 cm を超えると一定になったと報告してお り, 今回の結果と一致する ${ }^{12)}$ 。この結果から, 照射時 間 $8 \mathrm{~ms}$ (AEC 使用時のアクリル厚 $18 \mathrm{~cm}$ での照射時 間)で群分けを行い，補正係数を決定した。

被写体厚の推定については, 市川らの考案した胸部 の 2 方向撮影画像からの被写体厚推定法を用いた7).

これは, 胸部 2 方向の撮影画像から被写体厚を推定す る方法であり，事前実験として被写体厚既知の胸部 ファントムを用いて比較した結果, 実測值が 21.00 $\mathrm{cm}$, 画像からの推測值が $20.98 \mathrm{~cm}$ となり, 高い精度 が確認された。

胸部正面撮影時の ESD については，推定被写体厚 が $19 \mathrm{~cm}$ 以上 $25 \mathrm{~cm}$ 未満の症例において最小值が $0.02 \mathrm{mGy}$, 最大值が $0.08 \mathrm{mGy}$, 中央值が $0.033 \mathrm{mGy}$ となり, Japan DRLs 2020 の DRL 值 0.3 mGy よりは るかに低い值となった ${ }^{13)}$ 。これは，FPD で撮影を行っ ていることに加え, $0.3 \mathrm{mmCu}$ の付加フィルタを使用 しているためだと考えられる。シンチレータにヨウ化 セシウム蛍光体 (CSI) を用いた FPD は， CR と比べて 量子検出効率 (detective quantum efficiency: DQE) が 高いために低線量での撮影が可能と報告されてい る ${ }^{14)}$. また付加フィルタについては，Cuフィルタを 用いることで画質を劣化させることなく，入射表面線 量を 40-60\%低減できると報告されており ${ }^{15,16)}$ ，当院 でも CsI を用いた FPDを使用し, $0.3 \mathrm{mmCu}$ フィルタ を付加して胸部 X 線撮影を行っているために低線量 での撮影が可能となったと考えられる.

面積線量計を用いた ESD の推定については, Sdec を用いて臨床データから算出した ESD と面積線量計 の表示值に照射面積, 線質特性掞よび後方散乱の補正 を行った補正值の比較を行った。照射面積について は, 被写体厚によって焦点皮膚間距離が異なるために 
補正が必要と考えられる。しかし, 被写体厚を実測し た結果，全症例中 98\%が 15-25 cm の範囲に含まれて おり，被写体厚 $20 \mathrm{~cm}$ として照射面積の補正を行って も誤差は土5\%程度となるため, 今回は被写体厚 $20 \mathrm{~cm}$ での補正係数を全症例に用いた。その結果， ESD と $\mathrm{ESD}_{\mathrm{DAP}}$ は, $\mathrm{r}=0.99$ と非常に高い相関がみられ, 近似式 は $\mathrm{y}=1.06 \mathrm{x}-3.34$ となり, 誤差率は, $\pm 10 \%$ 程度であった。 以上より, 面積線量計の線質特性および後方散乱の 影響を補正することで面積線量計を用いて ESD の推 定が可能である。今回の推定式は,アクリル板と線量 計を用いた基礎実験のみで算出可能であり，被写体厚 の計測や被検者への線量計の装着を必要としないた め，簡便に患者被ばく管理を行う方法として有用と考 えられる。

\section{4. 結 語}

今回提案した面積線量計を用いた入射表面線量の推 定法により，簡便に被ばく管理を行うことが可能である.

\section{謝 辞}

本研究を行うにあたり，ご協力いただいた兵庫医科 大学病院放射線技術部の皆様に深く感謝申し上げます.

\section{利益相反}

筆頭著者の中野伸哉は富士フイルムメデイカル株式 会社の社員である。

それ以外の著者に開示すべき利益相反はない。

\section{参考文献}

1) ICRP. Radiological Protection in Medicine. ICRP Publication 105. Ann ICRP 2007; 37(6).

2）藤淵俊王, 加藤英幸, 橋本成世, 他. リアルタイム半導体 線量計の特性評価と一般撮影に扔ける入射表面線量測定. 日放技学誌 2006; 62(7): 997-1004.

3）江田和由, 甲斐倫明, 佐藤春雄, 他. 腹部 IVR の際の患者 の皮膚線量のリアルタイム測定. 日放技学誌 1998; 54(6): 792-796.

4）森剛彦, 武藤裕衣, 佐藤斉, 他. $X$ 線診断撮影条件の調査 に基づく被爆線量とわが国におけるガイダンスレベルの 提案. 日本医放会誌 2000; 60(7): 389-395.

5）J-RIME．最新の国内実態調査結果に基づく診断参考レベ ルの設定．http://www.radher.jp/J-RIME/report/DRLhoukoku syo.pdf (cited 2019. 12. 25).

6）坂本肇，中村修，弓削誠，他．面積線量計による患者被曝 管理の検討。日放技学誌 2000; 56(10): 1256-1265.

7）市川卓磨, 大野晃治, 浅田恭生. 臨床画像を用いた胸部撮 影における入射表面線量の評価一 2 方向撮影画像を用い た被写体厚の推定一. 日放技学誌 2018; 74(7): 661-666.

8）加藤秀起, 藤井茂久, 吉見勇治. 診断用 $X$ 線領域におけ る入射表面線量計算ソフト SDEC の開発. 日放技学誌 2009; 65(10): 1400-1406.
9）越田吉郎, 清水幸三, 宮地利明。面積線量計の特性解析と 空気カーマへの検討。日放技学誌 2001; 57(12): 1541-1547.

10） IEC/62C 国内委員会. IEC 基準の紹介一面積線量計一. 日放技学誌 $1979 ; 35(4):$ 511-520.

11）加藤秀起. 微分後方散乱係数を用いた診断 $X$ 線の後方散 乱係数算出法. 日放技学誌 2001; 57(12): 1503-1510.

12) 前川昌之. 後方散乱係数の再検討と近似曲面(討論会テー マ：『X 線検査における医療被ばく線量標準測定法』の確 立に向けて, 第 27 回計測分科会討論会 (2)). 計測分科会 誌 2006; 14(1): 10-12.

13) J-RIME. National diagnostic reference levels in Japan (2020) —Japan 2020 DRLs - https://www.radher.jp/J-RIME/report/ DRL2020_Engver.pdf (cited 2020. 08. 05).

14）小川憲一, 米田和夫, 奈良井昇, 他. フラットパネルディ テクタの画質評価と適正照射線量. 日放技学誌 2001; 57 (5): 587-592.

15) Martin C. The importance of radiation quality for optimisation in radiology. Biomed Imaging Interv J 2007; 3(2): e38.

16) Samei E, Dobbins JT, 3rd, Lo JY, et al. A framework for optimising the radiographic technique in digital X-ray imaging. Radiat Prot Dosimetry. 2005; 114(1-3): 220-229. 